CEPAL REVIEW 87 • DECEMBER 2005

\title{
The technical skills of information technology workers in Argentina
}

\author{
José Borello, Analía Erbes, \\ Verónica Robert, Sonia Roitter and Gabriel Yoguel
}

José Borello

Teacher-researcher,

Instituto del Conurbano, Universidad

Nacional de General Sarmiento (UNGS)

- jborello@ungs.edu.ar

Analía Erbes

Teacher-researcher,

Instituto de Industria, UNGS

- aerbes@ungs.edu.ar

Verónica Robert

Teacher-researcher,

Instituto de Industria, UNGS

- vrobert@gmail.com

Sonia Roitter

Teacher-researcher,

Instituto de Industria, UNGS

$\infty$ sroitter@ungs.edu.ar

Gabriel Yoguel

Teacher-researcher,

Instituto de Industria, UNGS

• gyoguel@ungs.edu.ar

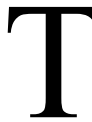

his article makes an assessment of Argentina's human resource skills in the field of information technology (IT). In various of the country's government, business and academic domains the quality and potential of domestic human resources in this area is taken for granted- a belief based on the country's rich, yet contradictory it history, but not founded on an analysis of the corresponding skills. This study aims to develop and apply a methodology to evaluate the skills of IT workers and highlight their problems and potentials, using the results of an electronic survey. The current features and heterogeneity of those human resources are interpreted in the light of the progress and setbacks experienced by the activity during the course of its evolution. 


\section{I}

\section{Introduction}

The fact that the information-technology sector has been hailed as the key to Argentina's modernization more than once in recent decades has enabled the country to develop an IT track record, both in the academic world and, to a lesser extent, in business activity. It could be argued that the idiosyncrasies of the sector and the current heterogeneity of its human resources stem from the advances and setbacks that have occurred during its development. Following the demise of the convertibility model (December 2001), keen interest in the development of this knowledge-intensive sector was rekindled, in the belief that there was a critical mass of high-quality human resources available to be exploited.

Nonetheless, the empirical evidence tends to cast doubt on whether sufficient capacities exist to fuel an expansion of the country's IT sector. Many studies of the use and production of information and communication technologies (ICTS), undertaken in Argentina over the last few years, have highlighted the obstacles faced in disseminating and developing a competitive software and IT service industry. Research into the problems of ICT dissemination reveal that these relate directly to firm size, the level of endogenous skills attained by participants, and the presence of business networks (Novick, 2002; Boscherini, Novick and Yoguel, 2003; Martin and Rotondo, 2005; Yoguel, Novick and others, 2004; Cabello and Moyano, 2005; Lugones, Bianco and others, 2003). These studies also show that firms use ICTs mostly for management tasks, which means scant dissemination and unsystematic use of complex tools, with few major changes arising from ICTs being introduced into production processes.

On the supply side, studies have shown that the domestic IT sector lacks a critical mass of top-notch firms, and is dominated by service activities rather than product development (López, 2003; Chudnovsky, López and Melitzko, 2001; Perrazo, Delbue and others, 1999). Moreover, the most dynamic sectors of the economy (the agribusiness and energy complexes) do not generate demands on the domestic IT sector that have

The authors are grateful for comments made on earlier versions of this paper by Alice Lam, Bengt-Ake Lundval, Franco Malerba and Gabriel Baum. the potential to fuel significant learning and increase the exportable supply of software.

A review of the existing bibliography highlights these problems of supply and demand and suggests that a crosscutting approach focused on human resources would contribute to a partial understanding of the relevant constraints. An assessment of the technical skills of IT human resources would therefore provide additional tools for analysing the sector's potential.

This article aims to develop and apply a methodology for assessing the skills of IT workers in Argentina, based on the results of an electronic survey. ${ }^{1}$ The intention is to provide tools to assess Argentina's chances of being able to significantly raise its capacity to solve complex IT problems, for both the domestic and the international market, over the next few years.

Recent publications on business organization and economic development have pointed out that, when studying activities related to new technologies, a human-resource approach complements the conventional enterprise-focused analysis (Markusen, 2002). It is firstly argued that new business forms can be identified that arise from interaction between firms and institutions rather than within them; and, secondly, that workers tend to carry out tasks in various places simultaneously, or frequently change firm or institution (Micheli, 2003). As a result, workers tend not to clearly identify with a given firm or institution, but rather with projects or crosscutting epistemic communities, on the legal boundaries of organizations (Nemirovsky and Yoguel, 2001). In information- and-knowledge-based activities, the relevant entities are "communities and networks of practice" (Brown and Duguid, 2000) and "knowledge communities" (Henry and Pinch, 2000), which serve as vehicles that traverse the formal boundaries of enterprises and institutions. Workers' skills are the key to creating dynamic competitive advantages, constructing networks and knowledge circulation, and explaining innovation within enterprises (Metcalfe, Ramlogan and Uyarra, 2002). Most studies agree that, given the nature of the activities

\footnotetext{
${ }^{1}$ The survey was performed jointly by the Argentine Society for Informatics and Operations Research, and Universidad Nacional General Sarmiento (the SADIO-UNGS survey).
} 
they undertake, human resources are an excellent lens through which to understand and analyse the sector (Ducatel, 1994).

To evaluate human resource capacities in the IT sector, a number of questions need to be answered, including the following: What are the different profiles of IT workers, and to what extent do those profiles stem from the sector's evolution? Do these workers have the capacities needed to develop a competitive local software and IT services industry, capable of meeting the challenges of more dynamic sectors in both the domestic and external markets? Does the local economic structure help to invigorate the sector? Do IT workers identify with any project in which they participate, or do they undertake individual activities?
Is the education system forming human resources capable of dealing with complex software and successfully adapting to ongoing technological changes? What is the relation between technical-skill creation and participation in networks and institutions? This article aims to answer some of these questions.

Following this introductory section, section II summarizes a number of structural elements of the IT sector and provides a stylized description of its evolutionary path in terms of capacity formation over the last few decades. Section III presents the conceptual and methodological framework and working hypothesis. Section IV reviews the data and tests the proposed hypothesis through cluster analysis. Lastly, section $\mathrm{V}$ sets out the main conclusions.

\section{II}

\section{Structure and evolution of information}

\section{technology in Argentina}

\section{Structural features and differences with respect to successful late-entrant countries}

Argentina occupies a relatively marginal position among late entrants to the international IT market (Anlló, Bezchinsky and others, 2003). Its IT sector is very small compared to those of successful entrants over the last 10 years, such as India, Ireland and Israel (Arora and Gambardella, 2005). The IT sales of Ireland and India are respectively 33 and 30 times larger than those of Argentina, while Israel's are 10 times larger. From the employment standpoint, the differences are 16 times in the case of India, but less marked in relation to the other two countries: Ireland has double the number of IT employees and Israel a relatively similar number to Argentina (roughly 15,000 people). This translates into major differences in sales per employee between the countries mentioned. Whereas in India this indicator is double that of Argentina, in Israel it is 10 times larger and in Ireland 17 times. In the latter country, the difference is largely explained by sales per employee in transnational enterprises (28 times higher) and to a lesser extent by local agents (four times higher). ${ }^{2}$

${ }^{2}$ The high levels of sales per employee in Ireland and Israel basically reflect the fact that the IT tasks performed in those countries are
There are other significant differences in terms of international participation: Argentina has a much lower export coefficient $(17 \%)$ than the other three countries $(75 \%)$; and its IT sector is relatively speaking also significantly smaller.

There are also substantial differences in relation to other Latin American countries: in Brazil sales and employment levels are, respectively, eight and nine times higher than in Argentina, despite basically serving the domestic market. Chile and Uruguay have relatively small IT sectors in terms of sales, although the latter has a particularly high export coefficient (33\%).

Nonetheless, various authors (including López, 2003; Anlló, Bezchinsky and others, 2003) agree that significant progress has been made in the IT sector in Argentina, at least in quantitative terms. This trend has been associated with the history of the sector, as noted

\footnotetext{
less labour-intensive. This is largely due to the prevalence of outsourcing in countries such as Ireland, where less complex and more labour-intensive tasks, such as codification and verification, are outsourced to countries such as India, where the hourly wage paid to programmers is lower. The indicator of sales per employee therefore cannot be equated to productivity, given the weight of imports (particularly in the case of Ireland, where the presence of transnational enterprises is crucial).
} 
below, and also with the creation of human resource capacities. Despite efforts made in the education system, there are significant shortcomings that arise partly from directional changes in programmes once considered strategic, and the recent haphazard emergence of a variety of IT courses and training institutes ${ }^{3}$-at the technical, professional and postgraduate levels-in the wake of the sector's vigorous expansion. This was accompanied by great diversity in terms of courses, contents, skill creation and course duration (Aguirre, 2003; Monteverde and Pérez, 2005), which has generated considerable uncertainty over the capacities of graduates at the various levels of training.

The first level -technical-professional secondary education- aims to develop programming, design and codification capacities and currently accounts for one third of the country's almost 60,000 it students. The second level -higher non-university technical education-aims to train systems analysts for the design, development, implementation and verification of software systems. It attracts over half of the students and involves some 30,000 people in courses lasting roughly three years. The third level -university degreetrains software engineers and graduates in IT systems, capable of establishing technological and methodological standards, constructing tools to enrich the development environment, and managing software processes. This group accounts for just over $10 \%$ $(7,000)$ of the country's IT students at all levels. Lastly, the postgraduate level, created only recently in Argentina, contains 37 programmes and presumably accounts for less than $1 \%$ of all it students. ${ }^{4}$

Courses offered by the first three levels vary widely in terms of contents and contact hours, sometimes operating under similar names. ${ }^{5}$ Moreover, it is doubtful that there are sufficient teachers to provide quality education in all of the institutions currently operating. Despite the rapid growth of such institutions, there are still many people who are self-taught in IT, or who

\footnotetext{
${ }^{3}$ Between 1997 and 2002, the number of graduates from IT courses grew by $151 \%$ (from 1,000 to 2,627). Graduates in applied sciences represented $12 \%$ of the total in 1997 , and had risen to $20 \%$ by 2002.

${ }^{4}$ For more disaggregated information see the annual report of the National Office for Educational Quality Information and Evaluation (DINIECE), reports issued by the University policy secretariat, and Anlló, Bezchinsky and others (2003).

${ }^{5}$ These courses include systems analyst, IT technician, software engineer, systems engineer, graduate [licenciado] in systems, graduate [licenciado] in IT, and graduate [licenciado] in computer sciences.
}

acquired their training on the job. ${ }^{6}$ As a result, it is hard to ascertain the scope and skills of existing human resources.

Furthermore, quality assessments are only available for a few undergraduate courses and postgraduate studies, and there are cases in which university training programmes are placed on the same level as those of non-university tertiary education. ${ }^{7}$ This reveals a considerable lack of knowledge of the quality of secondary and tertiary non-university training, and major variety in undergraduate and postgraduate studies.

The most significant shortcoming in many university courses concerns the lack of research that accompanies teaching activity. In some cases this results in low-productivity research areas and in other cases its nonexistence. Lack of research makes it impossible to distinguish between university courses and nonuniversity tertiary training institutes, thereby potentially devaluing university degrees. Moreover, the research areas of national universities are often more reflective of individual efforts than long-term institutional policies, which renders their activities highly unstable and atomized.

\section{Historical development of the IT sector}

The Iт sector in Argentina has a long tradition, dating back to the late 1950 s, which cannot be understood independently of the development of science and technology in the country, particularly during the period of import substitution industrialization (ISI). That development model established a pattern of specialization along with a set of institutions that contributed to local technological progress. The sector's evolution was not linear, however, but progressed in fits and starts (Azpiazu, Basualdo and Nochteff, 1990; Babini, 2003).

Local development of the IT sector continued during the 1960s and 1970s. In the first half of the 1960s, the Argentine IT sector became the Latin American leader of an incipient activity that was in its infancy worldwide; and progress was far more hardware-related than it would become a few decades later. In the 1970s and

\footnotetext{
${ }^{6}$ A situation that is revealed in the results of the SADIO-UNGS survey. ${ }^{7}$ Reports issued by the National University Evaluation and Accreditation Commission (CONEAU) contain recommendations such as the following: "A major effort needs to be made to change curricula and the profile of the teaching body to differentiate it from the training provided by many tertiary institutes" (www.coneau.gov.ar).
} 
1980s significant progress was made through both foreign direct investment (FDI) and domestic firms. The latter grew particularly strongly during that period, in the framework of an import substitution programme and technology transfer agreements with leading transnational enterprises operating in the sector.

While it is impossible to identify an clear breakpoint in the import substitution model, the interruption of democracy in 1976 was certainly a key date. The ISI development scheme was gradually dismantled, both as a specialization model and in terms of the institutions and regulations that were functional to it. The economy moved towards specialization based heavily on exploiting static comparative advantages, with market deregulation and reduced State participation in the economy.

The attempt to open up the economy in the late 1970 s, founded on the monetary approach to the balance of payments, did not necessarily entail a smaller State share in the production of goods and services, but it did mean a clean break with the institutions most closely associated with knowledge production. Following the debt crisis, and with the return of democracy in 1983, an attempt was made to revive some of the country's scientific and technical institutions. Nonetheless, the lack of a serious effort to replace specialization based on natural resources and intermediate products (commodities), with a scheme of static comparative advantages, helped to create a substantial mismatch between the capacities and knowledge developed in universities and research institutes and those needed by the productive system.

In the 1980s IT policy guidelines were drawn up for the first time, which were similar to proposals circulating in developed or rapidly industrializing countries. These guidelines, aimed at development of the electronics complex in general and the IT segment in particular, originated in material developed by the National Information Technology Commission which was created in 1984. The targets and instruments included tax reductions based on public tenders, preferences for domestically owned enterprises and "national purchase" policies for software products. There were also actions aimed at generating increasingly complex linkages, connecting local software supply with demand, forming specialist human resources, negotiating agreements with Latin American countries and promoting the creation of software in Spanish (Aspiazu, Basualdo and Nochteff, 1990).

Within that framework, the Argentine-Brazilian Programme of Research and Advanced Studies in
Information Technology (PABI) was created in 1986, through an agreement between the two countries for joint projects, exchange of human resources and the holding of events. The start of this programme revealed that, given of the lack of consolidated clusters in Argentina, the first stage had to be devoted to forming the necessary human resources. As a result the Argentine-Brazilian Information Technology Schools (EBAI), were created to help train a critical mass of researchers, upgrade degreelevel teaching, and create a regional school of thought in the discipline ${ }^{8}$ (Aguirre, 2003).

As part of this process of exchange with Brazil, and with a view to significantly improving human resource training, the Escuela Superior Latinoamericana de Informática (ESLAI) was established in 1986. Although this school prepared top-quality human resources, it failed to forge links with the business world which would have made it possible both to start new activities and to carry out work in conjunction with industry and the public sector (Aguirre, 2003). This shortcoming, caused by the predominance of the linear innovation model and compounded by an unfavourable macroeconomic framework, limited its chances of establishing itself in society and even called its continuity into question. Nonetheless, ESLAI partly helped to counteract the deficiencies in the quality and quantity of human resources working in IT: many people who joined the sector came from a previous generation trained in the context of the import substitution industrialization model (Aspiazu, Basualdo and Nochteff, 1990).

Policies designed in this period differed both from those implemented during ISI and from those associated with the economic liberalization of the 1970s, and thus constituted an innovative contribution that was unique in the sector's history. Nonetheless, these policies could not be sustained because of: (i) the absence of a global development vision that included a more complex specialization profile and the forging of links between the academic sector and the productive system; (ii) macroeconomic instability; and (iii) the regressive restructuring of the manufacturing sector and the State.

In the 1990s, trade and financial liberalization and market deregulation processes intensified, State participation in the economy was cut back, and the

\footnotetext{
${ }^{8}$ Between 1986 and 1989, four experiences were undertaken in Argentina and Brazil, and the human resource training process was interrupted in the late 1980s. As a result, 2000 students received training, and 60 original titles were published in Portuguese in Spanish; these were still being used on IT courses in the mid-1990s.
} 
pattern of specialization was deepened. During this period, the predominant view of technology was that the knowledge embedded in imported capital goods would percolate through the productive structure and society, serving as the key to productivity increase. The substantial growth of software and hardware imports that occurred during the period essentially relegated the sector's workers to tasks relating to the adaptation and modification of imported products. At the same time, the existence of closed standards and proprietary platforms in the imported products restricted possibilities for learning and intensified the sector's technological dependence. In contrast, the modernization of services triggered by the privatization process led to heavy demand for new software products, which was partly satisfied by local firms.

In the first half of the 1980 s, the policy instruments conceived in the previous decade were dismantled, in what represented a break in institutional continuity. Then, from the second half of that decade onwards, investments were made in the scientific and technological system that led to the creation of universities and various programmes to strengthen training and research activities. Examples include the founding of the National Science and Technology Promotion Agency, which manages competitive funds for scientific and technological projects; and the Fund to Improve the Quality of Degree-Level Teaching in the Sciences (FOMEC), a programme that aims to strengthen university training capacities. In the mid1980 s, the initial assessment of this programme confirmed the diagnosis later made by PABI in the second half of the decade, highlighting the human-resource weaknesses of the domestic IT sector. ${ }^{9}$ Of the US\$ 202 million granted by FOMEC, the $5 \%$ channelled into IT projects made it possible to improve hardware, replenish libraries and, in particular, to embark on significant human resource training at doctorate level. ${ }^{10}$

Although this programme, which ended in 1999, contributed to human resource formation, it unfolded against a backdrop of a significant separation between

\footnotetext{
${ }^{9}$ The 21 national universities offering IT courses had nearly 5,000 students with a graduation rate of just $3 \%$ of those entering in the same period. The entire teaching body included just two $\mathrm{PhDs}$, and hardware availability was minimal -in some cases one workstation for every 50 students. The same was true of libraries, which had 0.65 books per student. Only three universities had recently started to offer externally supervised $\mathrm{PhD}$ courses.

${ }^{10}$ Nearly $30 \%$ of the funding channelled into IT was destined for $\mathrm{PhD}$ courses, which contributed to the fact that the number of $\mathrm{PhDs}$ had risen to 70 in the early 2000 s.
}

science, technology and the productive system, and the consolidation of a pattern of productive specialization that meant low-complexity demand for the sector. Accordingly, despite the efforts that were made, the mismatch between the needs of the productive system and the capacities being generated by the education system were once again revealed. ${ }^{11}$ The human resource profile that the educational system was generating in the science and technology area was more attuned to the sectoral structure of imports than to local productive structure and specialization (Nemirovsky and Yoguel, 2004). This contradiction, which has been recurrent in different periods, resulted in a brain drain ${ }^{12}$ (Albornoz, Luchilo and others, 2003; Suárez, 2004).

The crisis in the predominant economic model of the 1990s, following the 2002 devaluation, has rekindled debate on the need to introduce more complex elements into the country's pattern of specialization. Inclusion of information- and knowledge-intensive activities, which are associated with increasing returns to scale and network creation and are subject to high income-elasticities of demand in a rapidly growing international market, would make it possible to exploit dynamic comparative advantages and reduce macroeconomic vulnerability (Reinert, 2002; Lall, 2001; Guerrieri, 1993; Dosi, Pavitt and Soete, 1990).

Against that backdrop, there has been growing interest among economic agents and the Government in the development of IT sector, which is seen as a key to the country's modernization. In particular, these protagonists recognize the sector's major potential, based essentially on its human resource capacities and the historical development that has helped generate the corresponding skills.

\footnotetext{
${ }^{11}$ The lack of public-policy emphasis on overcoming the separation between these domains is not peculiar to Argentina but also occurs in other countries of similar development level. In Brazil, for example, there are over 20 programmes promoting the IT sector, but apart from two that include human resource training and linkages with demand, the remainder target enterprise development, business creation and the incorporation of venture capital funds. The situation is similar in Uruguay, although the number of programmes is fewer. This contrasts with what is happening in India, where all these issues are addressed systematically and the importance of skill training processes in the creation of advantages for the sector is emphasized (Anlló, Bezchinsky and others, 2003). ${ }^{12}$ According to Jacovkis (2003), the history of computer science in Argentina was seriously affected by political events in the country between 1966 and 1983. Despite attempts to use neutral criteria, it is impossible to gain a realistic view while ignoring the terrible damage caused by the military dictatorships to the sector's incipient development.
} 


\section{III}

\section{Working hypothesis and analytical model}

Taking as a precedent the historical background reviewed above and the importance of workers' skills for the IT sector's performance, this section sets forth an analytical framework that relates the skill level achieved by workers both to the education system and to other factors, including the role of demand (via an analysis of the projects in which they participate) and the networks to which they belong. It can thus be seen that the sector's development potential depends partly on the workers' individual skills, but also on the various groupings and systems in which they participate. This approach to the problem evokes various authors and schools of thought that view competitiveness as a systemic phenomenon (Esser, Hillebrand and others, 1996). ${ }^{13}$

A number of authors have also shown that, given the inherent characteristics of this type of activity, IT workers are a very heterogeneous group, as revealed by productivity differences among similarly trained programmers (Cusumano, 2000). The definition of worker profiles depends not only on the type of technology with which they work or the products or services they develop, but also on other factors such as: (i) progress in the science and technology system; (ii) the coordination of workers in trade and technical associations and academic institutions; (iii) the characteristics and volume of local demand; and (iv) the evolutionary path of IT (Castells, 1996). ${ }^{14}$

Figure 1 offers a stylized version of the structure of possible relations between the various dimensions listed. From a theoretical standpoint, the most virtuous situations would feature strong interaction between all three dimensions. Supply from the education system

\footnotetext{
${ }^{13}$ On the specific case of ICTs, see National Research Council (1998).

${ }^{14}$ Castells (1996) argues that a new division of labour is emerging, based on three dimensions: activities that generate value, those that generate relations with the surroundings, and those that affect decision-making processes. Those dimensions give rise to following three overlapping worker typologies: (i) the commanders, the researchers, the designers, the integrators, the operators and the operated (in the value-making dimension); (ii) the networkers, the networked, the switched-off (in the relation-making dimension); and (iii) the deciders, the participators, and the executants (in the decision-making dimension).
}

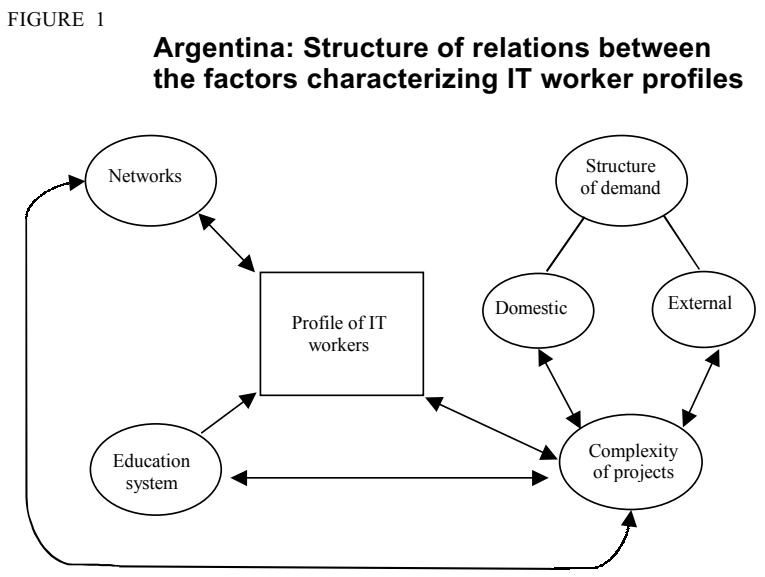

Source: Prepared by the author.

and the profile of domestic and external demand (influenced by the pattern of productive specialization and the type of dominant agents) both play key roles in project complexity, and hence in the level of IT workers' technical skills.

In this context, it is interesting to consider the extent to which the structure of demand and the complexity of development projects affect workers' learning possibilities, since complex activities present challenges that allow workers to learn through experience and interaction with others ("learning by doing" and "learning by interacting").

Although IT activities unfold inside firms and institutions, many are increasingly organized in projects that involve individuals from different firms, in conjunction with technologists and researchers attached to universities and laboratories, both State and private. This scale of project is particularly suited to measuring the skills possessed by workers, firms and institutions at a more aggregate, albeit still intermediate level; and for studying knowledge- and information-intensive activities (Lam, 2002), since the development level of virtual, institutional and personal networks is decisive for the circulation of codified and tacit knowledge. In virtuous cases in which networks are very important, "epistemic communities" are generated that facilitate innovation processes, which are thus shown not to be an individual phenomenon (David, Cowan and Forey, 
2000). In the specific case of Iт, the development of the Internet and virtual networks constitute a fundamental tool for communication and skill development. ${ }^{15}$

In terms of the relation between IT workers' technical skills and the formal level of education they have attained, the literature shows that this is a problematic issue that needs to be studied in terms of its conceptual and policy connotations. It has been argued that the ability to use knowledge and skills effectively and creatively -i.e. manipulation of words and data, oral and visual representations- for a large proportion of IT workers is more important than credentials expressed in terms of education level and field of study (López-Bassols, 2002; Micheli, 2003).

The significance of the relation between university and the IT sector goes beyond issues of training, to embrace aspects such as joint research and the establishment of formal or informal networks that link firms, universities and other institutions (Hetzkowitz and Leydesdorf, 1997). The literature on this subject has highlighted the importance of "bridge institutions" (Casalet, 2003), capable of coordinating supply and demand and creating a market.

Consequently, in activities that are closely related to research and development, various firms are operating with a network model that makes it possible to connect a firm's internal knowledge base to new knowledge generated in networks that traverse organizational boundaries (Lam, 2002). According to Lam, innovation activities in high technology sectors are increasingly being organized through a network of some type, with university-enterprise relations being encouraged in particular.

Networks that participate in knowledge circulation and skill formation include personal contacts, virtual networks and those belonging to institutions that bring IT workers together. In the last few years these have been included as research topics in several analyses made of information- and knowledge-related activities. Much of the corresponding work deals with formal and informal networks in highly developed local systems, such as Silicon Valley (Brown and Duguid, 2000; Castilla, Hwang and others, 2000; Saxenian, 2000). ${ }^{16}$

\footnotetext{
${ }^{15}$ An example of an epistemic community in the IT sector is the community of creators and users of free software. This is based on the existence and reproduction of a knowledge network, structured on the Internet and driven by collaboration that faces no other entry barrier than minimum skill requirements (Dale and Julien, 2003).

${ }^{16}$ The study of the social dimension of economic activity (Granovetter, 1985) has spawned numerous papers on the various types of personal and institutional networks that exist in economic
}

These and other studies argue that recognizing the importance of such networks is no longer sufficient; their nature and mode of operation need to be understood.

In the special case of relatively less developed countries, the theoretical relations suggested in figure 1 are less evident. Thus, for example, in Argentina the domestic demand generated by smaller firms is centred on national software supply, while external participation by the domestic IT sector is very weak. On the other hand, the demand for imported software and IT services means that numerous problems faced by the most dynamic sectors of the Argentine economy are being solved externally rather than by the domestic IT industry. ${ }^{17}$ All of this explains why гт projects carried out locally remain of low quality. Apart from anything else, the education system has a very low-key and somewhat one-way relation with it development projects, while networks are tenuously linked to the education system, and more directly related to project complexity. This is particularly important in the case of personal networks and, to a lesser extent, in the case of virtual and institutional ones. Relations between the domains identified thus lose their systematic focus and affect the level and use of Iт workers' skills.

Given the analytical approach used, the central hypothesis of this paper is that there are different profiles of IT workers based on their technological skills. These profiles are likely to be determined by the following elements: the tools they master (technologies and languages); the activities they undertake (services and development); the complexity of the projects in which they participate; the extent of their network use; and their level of formal education in IT.

The establishment of IT worker clusters by skill level will depend on the evolution of the sector and, in particular, the employment history of each cluster. Thus, the higher-skill cluster would be expected to include human resources whose employment histories reflect involvement with the sector's most successful experiences over the last few decades, or else younger human resources that have trained with them.

The fact that the formal education of IT workers is insufficient to explain their accumulated skills is

activity. These include studies on immigrant networks in Silicon Valley (Saxenian, 2000) and on the diaspora and its potential contribution to development.

${ }^{17}$ For example, those linked to traceability (quality assurance) in the agrifood industry, knowledge circulation in networks, codification of tacit knowledge, internalization of codified knowledge, and other items. 
shown by the presence of occupations requiring lower skills (the educational devaluation hypothesis), and also by the opposite hypothesis that self-training and tacit knowledge are important. Within this framework, the evolution of IT workers' skills would depend on their initial level, the role of the education system in their training, and the complexity of demand.

\section{IV}

\section{Main results of the survey and evaluation of the hypothesis}

This section describes the main characteristics of the panel of IT workers interviewed, and evaluates the paper's central hypothesis by jointly considering the relevant variables and applying factorial analysis of multiple correspondences to the main indicators that emerge from the survey (see appendix A). This technical statistical instrument is applied here basically to analyse factors that can help explain technological skills from a systemic point of view.

The survey questionnaire was designed by an interdisciplinary group involving professionals (mainly economists) from Universidad Nacional General Sarmiento and IT professionals from the Argentine Society for Informatics and Operations Research (SADIO). This entailed a demanding adaptation process to reconcile the working hypotheses with methods of capturing information in the sector without losing its complexity. ${ }^{18}$ The questionnaire, which was applied electronically, contained eight sections relating to: (i) the employment situation of the interviewees; (ii) the organization in which they work; (iii) the specific activities they carry out; (iv) the characteristics of the development projects in which they participate; (v) the use and creation of open-source software; (vi) institutional linkages and participation in networks; and (vii) their formal and informal education.

The panel interviewed included IT workers drawn from private enterprise, the public sector, training centres, specialist consultants and universities. They were asked to reply to the electronic questionnaire through various media. The survey was conducted between November 2003 and March 2004, and encompassed 197 workers. Following analysis and filtering of the replies, 167 records remained for statistical analysis.

${ }^{18}$ The questionnaire can be consulted at www.littec.ungs.edu.ar.

\section{The main characteristics of the panel surveyed and cross-section variables}

The panel displays several key features in terms of gender, age and geographic location. It is dominated by young men; $80 \%$ of its members are under 40 ; and $58 \%$ live in the Metropolitan area, with the remainder distributed among the province of Buenos Aires (11\%), Cordoba and Santa $\mathrm{Fe}$ ( $9 \%$ in each case), and other Argentine provinces (8\%). The final $5 \%$ of those interviewed are Argentines resident abroad.

Most of the interviewees have a high skill level. While half of them have completed university training, $17 \%$ have done postgraduate studies linked to IT, and just over a quarter possess incomplete university education. Among those holding university degrees, $60 \%$ are engineers and computer studies graduates, $29 \%$ systems analysts and graduates, and just $11 \%$ have studies unrelated to гт. These credentials are complemented by the fact that $30 \%$ of the interviewees hold some type of certification from firms providing the most widely used technologies, and nearly three quarters of the panel have a knowledge of English rated as good or better.

The employment rate among those interviewed is very high, with just $1.2 \%$ unemployed. Generally speaking, these are individuals with less than 10 years' work in IT ( $50 \%$ of the panel), a feature that is closely related to their age. Only $10 \%$ have been working in this activity for more than 25 years. A predominant feature is the high degree of heterogeneity in the job turnover rate among those interviewed. Whereas practically half of the panel had not changed job in the last five years, one fifth had changed at least three times, and $40 \%$ of the panel had been in their current job for under two years.

In terms of occupational category, most of those interviewed are employees (57\%), while just under one 
fifth are contracted for specific works or services, and the remainder are owners. Sixty percent of employees work in private firms, just under one fifth in the public sector (national, provincial, or municipal), and the remainder in academic or technological institutions or in non-governmental organizations. In contrast, among those working on fixed contracts, the relative share of the State and private enterprise is quite similar $(45 \%$ and $42 \%$, respectively).

Forty percent of those interviewed work in firms whose main activity is IT, while $60 \%$ are in firms or other types of organization involved in activities of other kinds. Among the former, $84 \%$ are engaged in activities of Iт development and services, $6 \%$ in services alone, and the remaining $10 \%$ only in development activities.

Lastly, with respect to the variables used to evaluate the hypothesis, just under one fifth of those interviewed have no mastery of computer languages or technologies. Nonetheless, the overall proportion of IT workers who do not use such languages is even larger, thereby highlighting problems of under-used skills. In terms of network use, personal contacts are extremely important; over half of those interviewed claim to have obtained their current job through such networks, and $78 \%$ of the panel uses them to find out about new technologies. The Internet communication tools use most frequently are specialized forums, followed by bulletins (newsletters) and mailing lists. Local workers made little use of tools such as Internet related chat (IRC). Lastly, nearly $30 \%$ of the panel are not involved in development projects. Projects tend to be short-term (50\% of them lasting less than a year) and involve a small number of people (under 10 individuals in 76\% of cases), which highlights their lack of complexity.

\section{Cluster analysis}

The use of cluster analysis made it possible to construct homogeneous groups by taking simultaneous account of the different factors affecting IT workers' technical skills. Multiple correspondences factorial analysis (MCFA) was used to summarize the relations that exist between the different modalities of the variables in the data matrix (active variables), and to obtain a small set of clusters comprising individuals displaying high levels of intra-cluster homogeneity and high extra-cluster heterogeneity. ${ }^{19}$ Illustrative variables were then taken

${ }^{19}$ This method operates by reducing the number of variables in the phenomenon being studied and forming factorial axes defined to focus the analysis on the variables and modalities that contribute into account that had not been considered when specifying the factorial axes, with a view to enriching the description of the axes and clusters.

The cluster analysis included seven active variables: (i) the complexity of the languages mastered by the interviewee; (ii) the complexity of the technologies mastered; (iii) the complexity of the development activities undertaken; (iv) the complexity of the services provided; (v) the level of formal education attained; (vi) the complexity of the projects in which the interviewee has participated; and (vii) network participation (see appendix A). Various illustrative variables were considered, as listed in appendix B, such as the type of course and level of the interviewee (table B.1), the medium in which interviewees consider they have gained most of their skills (table B.2), the type of organization in which they work (table B .3), job turnover (table B.4), age and years of work experience (tables B.5 and B.6), and gender (table B.7). Although the evolution of the sector is fundamental for defining the profiles of iT workers, the difficulties of incorporating such information into cluster analysis results in this factor being considered only in a contextual and descriptive fashion.

The MCFA was used to perform cluster analysis, and five homogeneous clusters were identified, ${ }^{20}$ which can be ranked by the level of technological skills achieved: very low, low, medium, high, and very high.

The fact that was possible to classify individuals in different homogeneous clusters, characterized by consistent combinations of modalities pertaining to different variables, reflects the strong interdependence of the dimensions mentioned in the hypothesis. Those dimensions can therefore be interpreted as helping to explain the different levels of technological skills among IT workers. The clusters listed in the previous paragraph are now described.

\section{a) Clusters with very low technological skills}

This cluster, which accounts for $18 \%$ of the panel, is dominated by service tasks ( $53 \%$ of its members are not involved in development activities); little or no mastery of information technologies and languages

most to explaining the problem at hand, thereby providing a manageable view of it.

${ }^{20}$ When interpreting the results, it should be borne in mind that the modalities of the variables relating to a given cluster show that individuals with the characteristic in question are significantly more represented in the cluster than in the sample as a whole; but this does not necessarily mean that all individuals in the cluster display that characteristic. 
( $80 \%$ of the cluster have no mastery of technologies, and $67 \%$ have no mastery of languages); and the nonuse of virtual networks (30\% of the cluster do not use networks, and $60 \%$ of all those who do not use networks are in this cluster). The illustrative variables (i.e. those not used in the cluster analysis) include a set of characteristics $^{21}$ that are useful for descriptive purposes: these are workers of over 40 years of age, who have been in the firm for an average of $4 \frac{1}{2}$ years, but whose length of service ranges from under two years to over four (tables B.4, B.5 and B.6).

Older individuals in the cluster display two possible employment paths. The more virtuous of these encompasses those who participated actively in the major progress made by the sector in the last few decades, and who were associated mainly with scientific and technological activities; they currently work mainly in academic institutions. The other employment path, applicable to most workers in the cluster, corresponds to individuals who came to IT through their employment and acquired training that was strictly functional to their working environment. ${ }^{22}$

An essential characteristic of this cluster involves having university training unrelated to IT (table B.1), little or no knowledge of English, and knowledge acquired in previous jobs. In this context, being selftaught is not a typical feature of the cluster (table B.2). Its members have low analysis and programming capacities, and their low proclivity for development activities means they tend to fulfil tasks that are not organized in projects. They also work in the private commerce and service sectors.

Other features of this cluster, while not characteristics, include belonging to firms whose main activity is not IT (57\%), and a higher relative proportion of women than in the other clusters (27\%) (table B.7).

\section{b) Cluster with low technological skills}

This is the largest cluster in the panel (39\%). It consists of workers who do not master information technologies and languages, or who have mastery of low complexity tools ${ }^{23}$ and undertake development tasks at the same level. Their activities are not organized

\footnotetext{
${ }^{21} \mathrm{~A}$ feature is considered a characteristic if in the contingency tables the difference between the proportion of the attribute in the cluster and in the total panel ( $\mathrm{Z}$ test) differs significantly from zero (at the $10 \%$ confidence level, at most).

${ }^{22}$ In that sense, their training was limited exclusively to the mastery of tools.

${ }^{23}$ Visual Basic, Clipper and Cobol among the languages; web platform and unified process among the technologies.
}

in projects. The cluster is dominated by individuals with incomplete university training.

The characteristic features of this cluster include the prevalence of young people (between 20 and 30 years of age) with less than 10 years' work experience (tables B.5 and B.6) and who have been in their job for an average of $4 \frac{1}{2}$ years (table B.4). These are individuals who have only recently joined the labour market, a large percentage of whom are working in the public sector (table B.3). Almost three quarters of the members of this cluster work in organizations in which the main activity is not IT. With regard to the trajectory of the members of this cluster, it might be thought that they are at a moment in their career when they can either move into medium- or high-skill clusters, or else stall, which would mean forming part of the previous cluster.

\section{c) Cluster with medium-level technological skills}

This is the smallest cluster, encompassing $10 \%$ of IT workers in the panel. Its members tend to have mastery of medium-complexity technologies and perform tasks in development activities. It is the first cluster notable for its mastery of IT languages and technologies and for participation in development projects. Its members have complete university education in the IT area (table B.1).

The characteristic features of the cluster include youth and high job turnover. Its members are under 30 years of age, and half of them have been in their current organization for less than three years. At the same time, almost $40 \%$ have changed their job three times in the last five years (table B.4). Although the members of this cluster participate in projects, these tend not to be very complex: they are relatively small (occupying between nine and 16 people), are undertaken basically for third parties in the form of specific assignments (i.e. they are custom-made products and are not intended for commercialization to several customers or en masse). In the opinion of the interviewees, the criticality $^{24}$ of the projects is high and the technical skills needed are of medium complexity. At the same time, undertaking such projects required links with large software firms and IT services. A relation can be established between the nature of the projects and the diversified nature of the demand from various sectors.

One characteristic of this cluster, which is absent from the previous ones, is that its members tend to

\footnotetext{
${ }^{24}$ As indicated in the survey form, the criticality of the software is measured in terms of the objective it pursues: e.g. the seriousness of the damage that could result from a possible failure.
} 
belong to firms in which IT is the main activity: $56 \%$ work in such firms.

\section{d) Cluster with high-level technological skills}

This cluster accounts for $15 \%$ of the panel. The development and service activities performed by its members are less complex than the skills they master. In terms of illustrative variables, the cluster is dominated by workers under 30 years of age (table B.6); turnover is very high, comparable to that of the previous cluster; but time spent in the current job is significantly less - a feature that is directly related to age since half of them have been in the labour market for fewer than nine years (tables B.4 and B.5). Although formal education is not a characteristic feature, nearly half of the cluster's members have university education related to IT, although not all of them have completed the respective course (tables B.1 and B.2). An element that distinguishes such individuals is their high level of English. The development projects they participate in seem to be inferior to the previous cluster, as indicated by the following: they last less than one year and involve between five and eight people; the criticality and complexity of the technical skills needed are evaluated by the interviewees as low; and, lastly, few linkages are required with large software and IT services firms. Most of this cluster works in private firms whose main activity is IT, and the presence of owners is a characteristic feature. The cluster could be identified as under-used (educational devaluation hypothesis), since the workers comprising it have significantly higher technical skills than those needed by the complexity of the tasks they are required to perform. If this mismatch serves to discourage them in their work, it would explain the high turnover.

e) Cluster with very high level technological skills

The remaining $18 \%$ of Iт workers belong to this final cluster which has more complex skills, ${ }^{25}$ the activities their members undertake, and the languages and technologies they have mastery of are both more advanced. They also make intensive use of virtual networks, have formal postgraduate education and carry out highly complex projects (table B.1). The characteristic features of the cluster are as follows: predominance of intermediate age groups (between 31 and 40 years), very little job turnover and much longer time spent in the current job than in other clusters - seven years on average, with $50 \%$ reporting over five

\footnotetext{
${ }^{25}$ Languages such as $\mathrm{C}++$, PHP, Perl, Lisp and Haskel, and others.
}

years in the job (tables B.4, B.5 and B.6). This feature, together with the level of formal education indicated and excellent mastery of English, are factors that determine the high level of technological skills among members of this cluster. At the same time, the quality of the projects in which they participate and their intensive network use help to ensure that their skills develop further over time. The projects in which they participate last more than 18 months, ${ }^{26}$ involve more than nine people, involve major technical difficulty and require high-capacity human resources. Carrying out this type of project requires establishing significant linkages with large software and IT firms, which marks a significant difference between this cluster and the others. A characteristic feature is that its members tend to hold permanent positions in academic or research institutions, so it is not surprising that the demand for their services comes from the IT and research and development sectors (table B.3). As mentioned above, the employment paths of workers in this cluster have been enriched by the most virtuous experiences in the evolution of the IT sector, despite its fits and starts.

Two further distinctive characteristics of this cluster are the high proportion of its members who are resident abroad (20\%) and the low proportion of women (13\%) (table B.7). A number of questions arise from this. Firstly, what role could Argentine IT workers located outside the country play in the development of the sector in Argentina? Secondly, why is the proportion of women in the IT sector generally low, and particularly among clusters with high technological skills?

\section{The dynamic of the different clusters}

From an evolutionary standpoint, it is essential to include a number of dynamic variables that explain the development of individual skills (Freeman, Soete and Efendioglu, 1995; Lall, 2001). To that end, the proportion of human resources that either performed no development or service activities at all, or else their activities of that type were of very low quality, was measured for 1991 and 2004 for each cluster.

In general terms, differences between clusters were detected in the evolution of such activities between 1991 and 2004. In clusters with low or very low technological skills, the proportion of individuals working in very low-complexity activities tended to rise, both in services

${ }^{26}$ This duration accounts for $54 \%$ of the projects in the cluster, but only $32 \%$ of projects in the total panel. 
and in development: whereas in $1999,61 \%$ of their members were engaged in low-complexity development activities, in 2004 the figure was $79 \%$. In contrast, in the cluster with very high level technological skills, the trend was very positive: while in 1999 almost half were not involved in complex development activities, by 2004 that proportion had fallen to $16 \%$.

This brief review of the employment dynamic suggests a number of interesting conclusions for reflection on IT human resources skills in Argentina. IT shows that there are significant blockages in the skill accumulation process which the dynamic of the labour market and activities within firms seem unable to resolve, whether for workers with less formal education and those carrying out simple tasks, or for a cluster with high skill levels that cannot raise the quality of the tasks undertaken. Accordingly, skill under-use does not seem to be a temporary phenomenon but for many individuals is a constant. Two distinct problems can therefore be identified. One is that individuals with low technological skills cannot find a virtuous career path, because of institutional constraints, the heterogeneity of the educational system, and lack of demand pressure. The other is the persistent under-use of resources, which stems basically from the weakness of demand for complex products.

\section{$\mathrm{V}$}

\section{Conclusions and final reflections}

This paper has evaluated the hypothesis that there are different IT worker profiles characterized by their technological skills; and it has reviewed how those profiles are determined by variables such as network participation, the educational system, the complexity of the projects undertaken and the structure of demand. The hypothesis was validated by analysing homogeneous clusters of IT workers based on the main variables that determine their technological skills. It was possible to place individuals in different homogeneous clusters because of the high level of interdependence between the dimensions considered in the hypothesis and their systemic nature. The dimensions considered thus help to explain the different levels of technological skills among IT workers.

The structure of demand seems to be fragmented and unspecialized. Few sales are made to the more dynamic sectors of the economy in which more complex demands could be generated. The main purchasers come from commerce and services generally; but in these sectors and in manufacturing industry, demand targeting the local market is less complex than that directed abroad. This affects both the type of projects undertaken and the skill training of IT workers, and at the same time results in those workers being underused. Domestic IT sectors are thus being asked mainly for adaptations to incorporate specific local features, whereas more complex demands from the most dynamic sectors of the domestic economy would encourage local IT firms to deal with more complex problems, in keeping with the competitive pressures they face. The productive sector and the institutional system still have difficulties in expressing their requirements in a way that local supply can decode and satisfy adequately.

Furthermore, there is little participation by IT workers in virtual and institutional networks, yet this type of linkage could generate skills that would complement those acquired in the formal education system. Personal networks seem to be used predominately for technological updating or job search, which makes knowledge circulation dependent on individual effort. Accordingly, the potential for selftraining and the creation of individual and cluster capacities offered by networks is neither fully nor systematically exploited by institutions, despite their being in a position to act on a broader cluster of individuals, firms and other organizations.

Although there is a positive relation between membership of the highest-skill cluster and the level of formal education attained, on-the-job and selftraining are also factors that help develop workers' skills. The formal education system creates a minimum threshold, from which workers should be able to internalize knowledge acquired in on-the-job training processes and through relations that are forged and created in their own professional development process.

The survey reveals that the IT labour market in Argentina suffers from problems that obstruct training processes and block progress towards higher-skill 
clusters. There seem to be obstacles that prevent workers with the necessary know-how from undertaking the activities for which they are trained, and hinder those with a mastery of simple tools from learning to use more complex ones.

Firstly, there are latent or potential capacities that are under-exploited, because of the supply and demand weaknesses indicated above. Secondly, there is limited growth and a lack of capacity for self-training in clusters that perform simple activities. Many workers with low technological skill levels have few opportunities to move into more virtuous clusters, because they lack the minimum skill threshold that would enable them to self-train by internalizing existing codified knowledge. The process of IT skill generation therefore needs to be improved to foster a virtuous circle of interaction between supply and demand.

In this paper we have presented a typology of individuals working in the Argentine IT sector, which is the outcome of a complex historical process involving construction (and destruction) of institutions and technical skills in the various attempts made by Government and the private sector to promote incipient national progress in the sector. This typology at least partly reflects that past history and the conflicting intentions of Argentine society towards building an IT sector within its borders.

The typology presented and reviewed in this paper, together with a description and analysis of the history of information technology in Argentina, raises a number of questions as to the potential of the Argentine IT sector in general and its human resources in particular. It can hardly be claimed that we are witnessing an imminent

APPENDIX A

$$
\text { Construction of indicators }
$$

\section{Tools mastered by the interviewee}

IT languages and technologies were ranked in terms of four criteria: up-to-datedness, importance in the local and international market, academic relevance and future prospects. Each language and each technology was graded on an exponential scale $(2,4$ and 8$)$ as best captured variability in terms of the criteria listed. The average points score was calculated for each individual, taking total non-mastery as zero. The capacities indicator was the simple average of the indicators of complexity of the different languages and technologies.

\section{Activities carried out by the interviewee}

Using a similar procedure, the tasks undertaken were divided into development activities and services, with points again being awarded on an exponential scale. This indicator was and spectacular expansion in exportable software supply, although the exportable supply of IT services has actually grown substantially in recent years. In this regard, a number of lines of action can be suggested based on the foregoing analysis.

In terms of projects, actions should be centred on: (i) raising the general complexity threshold of the software projects and IT services that the country can take on; (ii) strengthening relations between the IT sector and more dynamic activities, such as manufacturing, agriculture and mining; (iii) fostering demand for software and IT services from transnational enterprises located in Argentina; and (iv) exploiting the experience, contacts and knowledge possessed by Argentine IT professionals living abroad.

In terms of institutions and relations with the education sector, there is a need to improve the institutional framework of the IT sector and promote actions aimed at enhancing its relations with the education system.

With regard to more specific actions to develop technical capacities in IT human resources, it would be important to: (i) overcome the barriers that currently exist in the labour market to exploit all existing capacities and promote genuine careers or development paths that raise the general level of the country's IT human resources; and (ii) formulate and apply specific policies based on the heterogeneous nature of the worker profiles in the sector.

Lastly, it would be interesting to complement the dynamic view of IT workers offered in this paper with a systemic account of the multiple factors that determine the quality of the respective human resources.

also defined as a simple average of the indicators of the various development and service activities. The basic difference between the capacities indicator of tools mastered and the indicator of activities undertaken is that, in the second case, zero points were not awarded if a given activity was not undertaken. Thus, while an individual's mastery of more than one tool was positively recognized, carrying out more than one activity at a time was not rewarded.

Indicator of the degree of network use

Data from the survey indicated the degree of use of each virtual communication tool with points ranging from one to five: a score of 1 being assigned to non-use and 5 to the highest frequency of use. The continuous indicator, which also ranges from one to five, is calculated as the average of the scores awarded for each instrument. 
Indicator of project complexity

This indicator was calculated as an average between (i) project duration in months; (ii) number of people involved; and (iii) a cross between the project's objective and the destination market. Table A.1 gives details of these variables.

TABLE A.1

\section{Argentina: Project variables}

\begin{tabular}{|c|c|c|c|}
\hline Points & $\begin{array}{l}\text { Duration } \\
\text { (months) }\end{array}$ & $\begin{array}{c}\text { Size (No. people } \\
\text { involved) }\end{array}$ & Objective and target market \\
\hline 1 & $0-6$ & $0-2$ & Internal to the firm \\
\hline 2 & $7-12$ & $3-4$ & $\begin{array}{l}\text { Specific order from a } \\
\text { customer in Argentina }\end{array}$ \\
\hline 3 & $13-18$ & $5-8$ & To be commercialized in Argentina \\
\hline 4 & $19-24$ & $9-16$ & Specific order from a customer abroad \\
\hline 5 & 25 or more & 17 or more & To be commercialized abroad \\
\hline
\end{tabular}

The final indicator is calculated as the average of points awarded on these three variables.

\section{Indicator of formal education}

The interviewees' level of formal education was divided in four levels:

(i) Formal education unrelated to IT

(ii) Incomplete university education related to IT

(iii) Completed university education related to IT

(iv) Postgraduate education related to IT

\section{APPENDIX B}

Statistical data

TABLE B.1

Argentina: Relation between formal education and technological skill level in IT worker clusters

(Percentages)

\begin{tabular}{|c|c|c|c|c|c|c|c|}
\hline \multirow[b]{2}{*}{$\begin{array}{l}\text { Skill level of } \\
\text { each cluster }\end{array}$} & \multicolumn{7}{|c|}{ Formal education classified by type of course and level } \\
\hline & $\begin{array}{l}\text { Tertiary } \\
\text { complete }\end{array}$ & $\begin{array}{l}\text { University } \\
\text { incomplete }\end{array}$ & $\begin{array}{c}\text { University } \\
\text { unrelated } \\
\text { to IT }\end{array}$ & $\begin{array}{c}\text { Analysts and } \\
\text { graduates } \\
\text { in systems }\end{array}$ & $\begin{array}{l}\text { Engineers and } \\
\text { graduates in } \\
\text { computers } \\
\text { cience }\end{array}$ & $\begin{array}{l}\text { University with } \\
\text { postgraduate } \\
\text { studies related } \\
\text { to IT }\end{array}$ & $\begin{array}{c}\text { Not } \\
\text { specified }\end{array}$ \\
\hline 1. Very low & 8.7 & $8.7^{\mathrm{b}}$ & $16.7^{b}$ & 16.7 & 33.3 & 10.0 & $10.0^{\mathrm{b}}$ \\
\hline 2. Low & 7.6 & $45.5^{\mathrm{b}}$ & 3.0 & 15.2 & 24.2 & $3.0^{\mathrm{b}}$ & 1.5 \\
\hline 3. Medium & 0.0 & 12.5 & 6.3 & 18.8 & 43.8 & 18.8 & 0.0 \\
\hline 4. High & 11.5 & 23.1 & 3.8 & 11.5 & 30.8 & 19.2 & 0.0 \\
\hline 5. Very high & 6.5 & $9.7^{\mathrm{c}}$ & 0.0 & 6.5 & 25.8 & $48.4^{b}$ & 3.2 \\
\hline Total & 7.1 & 25.4 & 5.3 & 13.6 & 29.0 & 16.6 & 3.0 \\
\hline
\end{tabular}

Source: Prepared by the author on the basis of data from the SADIO-UNGS survey on the technological skills of IT workers.

${ }^{a}$ The probability of accepting the null hypothesis of no association is $0 \%$.

b Z-test significant at $1 \%$.

${ }^{c}$ Z-test significant at $10 \%$. 
TABLE B.2

Argentina: Relation between the medium in which skills were acquired and technological skill level in IT worker clusters ${ }^{a}$

(Percentages)

\begin{tabular}{|c|c|c|c|c|c|}
\hline \multirow[b]{2}{*}{$\begin{array}{l}\text { Skill level } \\
\text { of each cluster }\end{array}$} & \multicolumn{5}{|c|}{ Medium in which workers consider they acquired their main skills } \\
\hline & Self-taught & $\begin{array}{c}\text { Formal } \\
\text { education }\end{array}$ & $\begin{array}{l}\text { Training } \\
\text { courses }\end{array}$ & $\begin{array}{l}\text { Previous } \\
\text { jobs }\end{array}$ & $\begin{array}{l}\text { Current } \\
\text { job }\end{array}$ \\
\hline 1. Very low & $2.0^{\mathrm{b}}$ & 22.0 & 18.7 & $42.0^{\mathrm{c}}$ & 15.3 \\
\hline 2. Low & 16.7 & 27.3 & 10.6 & 19.7 & 25.8 \\
\hline 3. Middle & 20.0 & 20.0 & 13.7 & 26.2 & 20.0 \\
\hline 4. High & $23.1^{\mathrm{c}}$ & 34.6 & 15.4 & 19.2 & 7.7 \\
\hline 5. Very high & 16.1 & 35.5 & $3.2^{\mathrm{c}}$ & 29.0 & 16.1 \\
\hline Total & 15.3 & 28.3 & 11.7 & 25.9 & 18.8 \\
\hline
\end{tabular}

Source: Prepared by the author on the basis of data from the SADIO-UNGS survey on the technological skills of IT workers.

${ }^{a}$ The probability of accepting the null hypothesis of no association is $0.06 \%$.

b Z-test significant at $1 \%$.

${ }^{c}$ Z-test significant at $10 \%$.

TABLE B. 3

\section{Argentina: Relation between the type of organization in which employed and technological skill level in IT worker clusters ${ }^{a}$ \\ (Percentages)}

\begin{tabular}{lcccc}
\hline & \multicolumn{4}{c}{ Type of organization in which employed } \\
\cline { 2 - 5 } $\begin{array}{l}\text { Skill level } \\
\text { of each cluster }\end{array}$ & $\begin{array}{c}\text { Private } \\
\text { enterprise }\end{array}$ & $\begin{array}{c}\text { Non-governmental } \\
\text { organization }\end{array}$ & $\begin{array}{c}\text { Academic or research } \\
\text { institution }\end{array}$ & $\begin{array}{c}\text { Public } \\
\text { sector }\end{array}$ \\
\hline 1. Very low & 76.7 & 3.3 & $0.0^{\mathrm{b}}$ & 20.0 \\
2. Low & 49.2 & 4.8 & 7.9 & $38.1^{\mathrm{c}}$ \\
3. Medium & 75.0 & 6.3 & 6.3 & 12.5 \\
4. High & 88.0 & 0.0 & $0.0^{\mathrm{b}}$ & 12.0 \\
5. Very high & 56.7 & 0.0 & $33.3^{\mathrm{c}}$ & 10.0 \\
Total & 64.0 & 3.0 & 9.8 & 23.2 \\
\hline
\end{tabular}

Source: Prepared by the author using data from the SADIO-UNGS survey on the technological skills of IT workers.

${ }^{a}$ The probability of accepting the null hypothesis of no association is $0 \% . \quad{ }^{b}$ Z-test significant at $10 \% . \quad{ }^{c}$ Z-test significant at $1 \%$.

TABLE B.4

Argentina: Relation between job turnover and technological skill level in IT worker clusters (Percentages)

\begin{tabular}{lcccc}
\hline & \multicolumn{4}{c}{ Job turnover } \\
\cline { 2 - 5 } $\begin{array}{l}\text { Skill level of } \\
\text { each cluster }\end{array}$ & $\begin{array}{c}\text { No } \\
\text { turnover }\end{array}$ & $\begin{array}{c}\text { Turnover } \\
\text { once }\end{array}$ & $\begin{array}{c}\text { Turnover } \\
\text { twice }\end{array}$ & $\begin{array}{c}\text { Turnover } \\
\text { three times }\end{array}$ \\
\hline 1. Very low & 50.0 & 23.3 & 16.7 & 10.0 \\
2. Low & 47.0 & 15.2 & 15.2 & 22.7 \\
3. Middle & 31.3 & 18.8 & 12.5 & $37.5^{\mathrm{a}}$ \\
4. High & 38.5 & 19.2 & 7.7 & $34.6^{\mathrm{a}}$ \\
5. Very high & 60.0 & 23.3 & 10.0 & $6.7^{\mathrm{a}}$ \\
Total & 47.0 & 19.0 & 13.1 & 20.8 \\
\hline
\end{tabular}

Source: Prepared by the author on the basis of data from the SADIOUNGS survey on the technological skills of IT workers.

${ }^{\text {a }}$ Z-test significant at $10 \%$.
TABLE B.5

Argentina: Relation between work experience and technological skill level in IT worker clusters $^{a}$

(Percentages)

Skill level of $\quad$ Years of work experience in the sector

\begin{tabular}{lllll} 
each cluster & Less than 10 & $11-20$ & $21-30$ & over 30 \\
\hline
\end{tabular}

\begin{tabular}{lllll}
\hline 1. Very low & 40.0 & 36.7 & 23.3 & 0.0
\end{tabular}

2. Low $\quad 62.1^{\mathrm{b}} \quad 27.3 \quad 9.1 \quad 1.5$

$\begin{array}{lllll}\text { 3. Middle } & 62.5 & 31.3 & 6.3 & 0.0\end{array}$

$\begin{array}{lllll}\text { 4. High } & 61.5 & 23.1 & 7.7 & 7.7\end{array}$

$\begin{array}{lllll}\text { 5. Very high } & 16.1^{\mathrm{c}} & 48.4 & 22.6 & 12.9^{\mathrm{b}}\end{array}$

$\begin{array}{lllll}\text { Total } & 49.7 & 32.5 & 13.6 & 4.1\end{array}$

Source: Prepared by the author on the basis of data from the SADIOUNGS survey on the technological skills of IT workers.

${ }^{\text {a }}$ The probability of accepting the null hypothesis of no association is $0.02 \%$.

${ }^{\mathrm{b}}$ Z-test significant at $10 \% . \quad{ }^{\mathrm{c}}$ Z-test significant at $1 \%$. 
TABLE B.6

Argentina: Relation between age and technological skill level in IT worker clusters ${ }^{a}$

\begin{tabular}{lcccc}
\hline & \multicolumn{4}{c}{ Age } \\
\cline { 2 - 5 } $\begin{array}{l}\text { Skill level of } \\
\text { each cluster }\end{array}$ & $21-30$ & $31-40$ & $41-50$ & 51 and older \\
\hline 1. Very low & 13.3 & 36.7 & 33.3 & $16.7^{\mathrm{b}}$ \\
2. Low & $47.0^{\mathrm{c}}$ & 28.8 & 19.7 & 4.5 \\
3. Middle & 50.0 & 31.3 & 12.5 & 6.3 \\
4. High & 46.2 & 38.5 & $7.7^{\mathrm{b}}$ & 7.7 \\
5. Very high & $9.7^{\mathrm{d}}$ & 51.6 & 29.0 & 9.7 \\
Total & 34.3 & 36.1 & 21.3 & 8.3 \\
\hline
\end{tabular}

Source: Prepared by the author using data from the SADIO-UNGS survey on the technological skills of IT workers.

a The probability of accepting the null hypothesis of no association is $0.07 \%$.

${ }^{\mathrm{b}}$ Z-test significant at $10 \%$.

${ }^{\mathrm{c}} \mathrm{Z}$-test significant at $1 \%$.

d Z-test significant at $1 \%$.
TABLE B.7

$$
\begin{aligned}
& \text { Argentina: Relation between gender and } \\
& \text { technological skill level in IT worker clusters } \\
& \text { (Percentages) }
\end{aligned}
$$

\begin{tabular}{lcl}
\hline & \multicolumn{2}{c}{ Sex of worker } \\
\cline { 2 - 3 } Cluster skill level & Female & Male \\
\hline 1. Very low & $26.7^{\text {a }}$ & 73.3 \\
2. Low & 18.2 & 81.8 \\
3. Middle & 6.2 & 93.8 \\
4. High & 15.4 & 84.6 \\
5. Very high & 12.9 & 87.1 \\
Total & 17.2 & 82.8 \\
\hline
\end{tabular}

Source: Prepared by the author using data from the SADIO-UNGS survey on the technological skills of IT workers.

${ }^{a}$ Z-test significant at $10 \%$.

\section{Bibliography}

Aguirre, J. (2003): La ESLAI: advenimiento, muerte prematura y proyección, Newsletter de Sadio, Buenos Aires, December.

Albornoz, M., L. Luchilo and others (2003): El talento que se pierde. Aproximaciones al estudio de la inmigración de profesionales, investigadores y tecnólogos argentinos, Documento de trabajo, No. 4, Buenos Aires, Centro Redes.

Anlló, G., G. Bezchinsky and others (2003): El caso de la industria de software y servicios informáticos en Argentina, estudio JICA/CEPAL sobre fuentes de crecimiento económico en Argentina, Buenos Aires. Available in <www.eclac.cl/ argentina $>$.

Arora, A. and A. Gambardella (2005): From Underdogs to Tigers. The Rise and Growth of the Software Industry in Brazil, China, India, Ireland and Israel, London, Oxford University Press.

Azpiazu, D., E. Basualdo and H. Nochteff (1990): Los límites de las políticas industriales en un período de reestructuración regresiva: el caso de la informática en Argentina, Desarrollo económico, vol. No. 118, Buenos Aires, Institute of Economic and Social Development (IDES).

Babini, R. (2003): La Argentina y la computadora. Crónica de una frustración, Buenos Aires, Ed. Dunken.

Borillo, J., V. Robert and G. Yoguel (2005): Para pensar la informática en la Argentina: Desafíos a la especialización y a la competitividad, Buenos Aires, Universidad Nacional de General Sarmiento (UNGS)/Editorial Prometeo, in press.

Boscherini, F., M. Novick and G. Yoguel (2003): Nuevas tecnologías de información y comunicación. Los límites en la economía del conocimiento, Buenos Aires, Miño.

Brown, J. and P. Duguid (2000): Mysteries of the region: knowledge dynamics in Silicon Valley, in L. Chong-Moon, W. Miller and others (eds.), The Silicon Valley Edge: An Habitat for Innovation and Entrepreneurship, Stanford, Stanford University Press.

Cabello, R. and R. Moyano (2005): Incorporación de TIC en el sistema educativo. Las restricciones de las competencias endógenas de los educadores, in R. Borello and G. Robert (eds.), Para pensar la informática en la Argentina: desafios a la especialización y a la competitividad, Buenos Aires, Editorial Prometeo/UnGS, in press.
Casalet, M. (2003): La conformación de un sistema institucional territorial en dos regiones: Jalisco y Chihuahua vinculadas con la maquila de exportación, in F. Boscherini, M. Novick and G. Yoguel, Nuevas tecnologias de información y comunicación. Los límites en la economía del conocimiento, Buenos Aires, Miño.

Castells, M. (1996): The Rise of the Network Society, vol. 1, Oxford, Blackwell.

Castilla, E., H. Hwang and others (2000): Social networks in Silicon Valley, in L. Chong-Moon, W. Miller and others (eds.), The Silicon Valley Edge: An Habitat for Innovation and Entrepreneurship, Stanford, Stanford University Press.

Chudnovsky, D., A. López and S. Melitzko (2001): El sector de software y servicios informáticos en la Argentina. Situación actual y perspectivas de desarrollo, Documento de trabajo, No. 27, Buenos Aires, Research Centre for Industrial Transformation (CENIT).

Cusumano, M. (2000): Making large teams work like small teams: product development at Microsoft, in U. Jürgens (ed.), New Product Development and Production Networks, Berlin, Springer-Verlag.

Dale, J.M. and N. Julien (2003): 'Libre' software: turning fads into institutions?, Research Policy, No. 32, Amsterdam, Elsevier.

David, P., R. Cowan and D. Forey (2000): The explicit economics of knowledge codification and tacitness, Industrial and Corporate Change, vol. No. 2, Oxford, Oxford University Press.

Dosi, G., A. Pavitt and L, Soete (1990): The Economics of Technical Change and International Trade, New York, New York University Press.

Ducatel, K. (ed.) (1994): Employment and Technical Change in Europe. Work Organization, Skills and Training, London, Edward Elgar Publishing Limited.

Esser, K., W. Hillebrand and others (1996): Systemic competitiveness: a new challenge for firms and for government, CEPAL Review, No. 59, LC/G.1931-P, Santiago, Chile, August.

Freeman, Ch., L. Soete and U. Efendioglu (1995): Diffusion and the employment effects of information and communication 
technology, International Labour Review, vol. 134, No. 4-5, Geneva, International Labour Organization.

Granovetter, M. (1985): Economic action and social structure: the problem of embeddedness, American Journal of Sociology, vol. 91, Chicago, The University of Chicago Press.

Guerrieri, P. (1993): International Competitiveness, Trade Integration and Technological Independence in Major LatinAmerican Countries, Naples, Universita degli Studi di Napoli Federico II, unpublished.

Henry, N. and S. Pinch (2000): Spatialising knowledge: placing the knowledge community of sport valley, Geoforum, vol. 31, Amsterdam, Elsevier.

Hetzkowitz, H. and L. Leydesdorf(1997): Universities and the Global Knowledge Economies. The Triple Helix of UniversitiesIndustries-Government Relations, London, Pinter.

Jacovkis, P. (2003): Breve historia de la computación en la Argentina, available in www.sadio.org.ar.

Lall, S. (2001): Competitiveness, Technology and Skills, Cheltenham, United Kingdom, Edward Elgar.

Lam, A (2002): Skills and Careers of R\&D Knowledge Workers in the Network Economy, document prepared for the 13 IIRA World Congress (Berlin, 2003), Uxbridge, Middlesex, London, School of Business and Management, Brunel University.

López, A. (2003): El sector de software y servicios informáticos en la Argentina ¿es posible una inserción exportadora sostenible?, in F. Boscherini, M. Novick and G. Yoguel, Nuevas tecnologías de información y comunicación. Los límites en la economía del conocimiento, Buenos Aires, Miño.

López-Bassols, V. (2002): Іст Skills and Employment, sTI Working Papers, DSTI/DOC(2002)10, Paris, Organization for Economic Co-operation and Development (OECD).

Lugones, G., C. Bianco and others (2003): Indicadores de la sociedad del conocimiento e indicadores de innovación. Vinculaciones e implicancias conceptuales y metodológicas, in F. Boscherini, M. Novick and G. Yoguel, Nuevas tecnologías de información y comunicación. Los límites en la economía del conocimiento, Buenos Aires, Miño.

Markusen, A. (2002): Targeting Occupations in Regional and Community Economic Development, Minnesota, University of Minnesota, Humphrey Institute of Public Affairs, unpublished.

Martin, S. and S. Rotondo (2005): Redes de proveedores en la industria manufacturera: un análisis desde la difusión de Tics y las competencias endógenas, in R. Borello and G. Robert (eds.), Para pensar la informática en la Argentina: desafios a la especialización y a la competitividad, Buenos Aires, Editorial Prometeo/Ungs, in press.
Metcalfe, J. R. Ramlogan and E. Uyarra (2002): Economic Development and the Competitive Process, Working Paper, No. 36, Manchester, University of Manchester, Centre for Research on Innovation and Competition.

Micheli, J. (2003): El trabajo de digitofactura en la economía postindustrial, Espacios globales: espacios del capitalismo, Mexico City, Ed. Carmen Bueno, in press.

Monteverde, H. and A. Pérez (2005): Sobre ventanas de oportunidad $\mathrm{y}$ aportes que puede hacer el sistema educativo, in R. Borello and G. Robert (eds.), Para pensar la informática en la Argentina: desafios a la especialización y a la competitividad, Buenos Aires, Editorial Prometeo/Ungs, in press.

National Research Council (1998): Fostering Research on the Economic and Social Impacts of Information Technologies. Report of a Workshop, Washington, D.C., National Academy.

Nemirovsky, A. and G. Yoguel (2001): Dynamics of HighTechnology Firms in the Silicon Valley, Working Paper, No. 01-03, Aalborg, Aalborg University, Department of Business Studies.

(2004): Renacimiento de Argentina a través de una economía basada en el conocimiento, el rol de los profesionales argentinos en el exterior, Buenos Aires, Instituto de Industria, Universidad Nacional de General Sarmiento, in $<$ www.littec.org $>$.

Novick, M. (2002): La dinámica de oferta y demanda de competencias en un sector basado en el conocimiento en la Argentina, Desarrollo productivo series, No. 119, LC/L.1696P, Santiago, Chile, ECLAC. United Nations publication, Sales No.: S.02.II..G.8.

Perazzo, R., M. Delbue and others (1999): Oportunidades para la producción y exportación de Software, Documento de trabajo, No. 9, Buenos Aires, Agencia Nacional de Promoción Científica y Tecnológica.

Reinert, E. (2002): El papel de la tecnología en la creación de ricos y pobres: el subdesarrollo en un sistema schumpeteriano, Cuadernos de difusión, year 7, No. 12, Lima, Escuela Superior de Administración de Empresas (ESAN).

Saxenian, A. (2000): The origins and dynamics of production networks in Silicon Valley, in M. Kenney (ed.), Understanding Silicon Valley: The Anatomy of an Entrepreneurial Region, Stanford, Stanford University Press.

Suárez, D. (2004): Fuga de cerebros argentina: un fenómeno que continúa. Available in <www.littec.org $>$.

Yoguel, G., M. Novick and others (2004): Información y conocimiento: la difusión de las Tic en la industria manufacturera argentina, CEPAL Review, No. 82, LC/G.2220P, Santiago, Chile, April. 